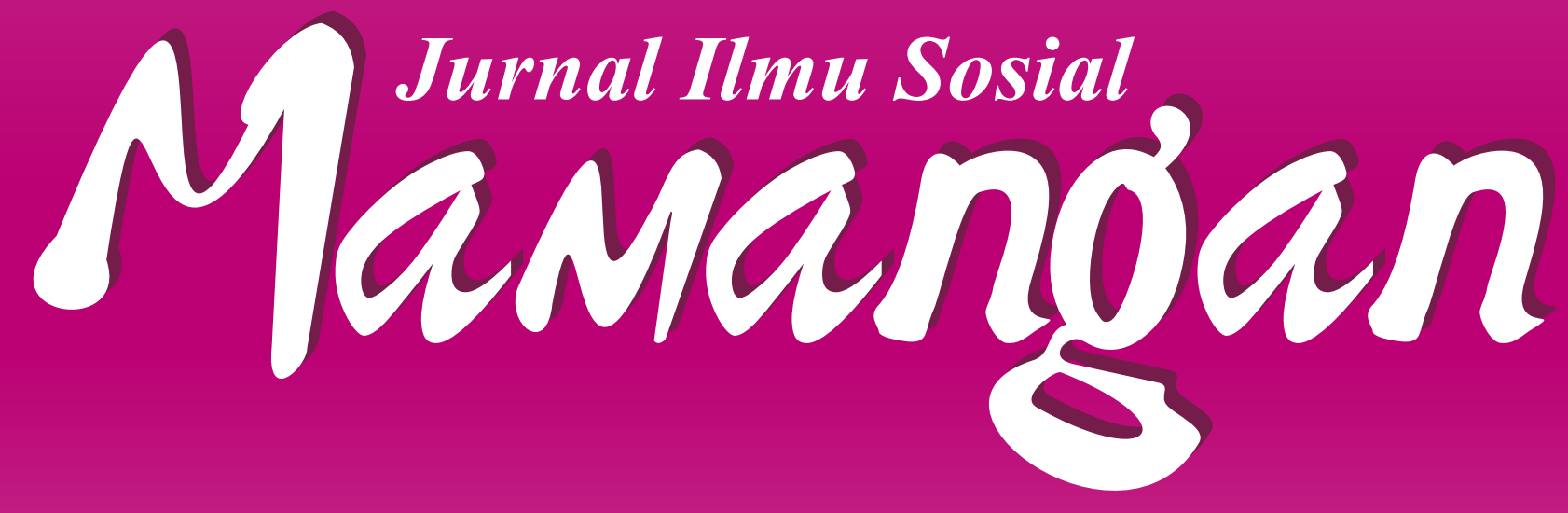

Seni Tradisi, Jatidiri dan Strategi Kebudayaan

Heddy Shri Ahimsa-Putra

Sejarah dan Nilai Songket Pandai Sikek

Silvia Devi

Budaya dalam Lintasan Sejarah: Booming Nonton Bioskop di Padang Tempo Dulu

Meri Erawati

Paradoksal Gaya Sosial Global; Kajian Budaya dalam Memahami Kesadaran Kolektif di Tengah Booming Batu Akik

Silfia Hanani

Gaya Kehidupan Malam Remaja di Kota Padang; Suatu Kajian Subkultur di Tempat Hiburan Malam Kota Padang

Faishal Yasin

Perlawanan Kaum Muda terhadap Hegemoni Radikalisme Agama dalam Bentuk-Bentuk Budaya Populer

Yusar

Gaya Interaksi \& Integrasi Sosial Anak Muda Rantau: Kasus Mahasiswa Kost di Air Tawar Barat, Kota Padang Darmairal Rahmad 


\section{PROGRAM STUDI PENDIDIKAN SOSIOLOGI STIIIP PGRI SUMATEPA BARAT}

\section{Visi}

"Menjadi Program Studi yang terkemuka di bidang pendidikan keguruan sosiologi dan kompetitif secara nasional di tahun 2026"

\section{Misi}

$>$ Melaksanakan dan mengembangkan pendidikan dan pengajaran yang berbasis kepada pengembangan kecerdasan intelektual (hard skill) dan kecerdasan emosional (soft skill) untuk memperoleh kecakapan hidup (life skill),

> Melaksanakan dan mengembangkan penelitian dan pengabdian di bidang pendidikan dan pengajaran serta bidang lain sesuai dengan keilmuan fakultas dan program studi,

$>$ Mengembangkan Ilmu Pengetahuan, Teknologi, dan Seni (IPTEKS) yang dilandasi profesionalisme,

$>$ Menyelenggarakan perguruan tinggi yang akuntabel, efisien, efektif, transparan, relevan dan mandiri,

$>$ Mengembangkan kerjasama dengan berbagai lembaga/instansi terkait dan stakeholders untuk keberlanjutan pelaksanaan program dan/atau pembukaan program studi baru. 


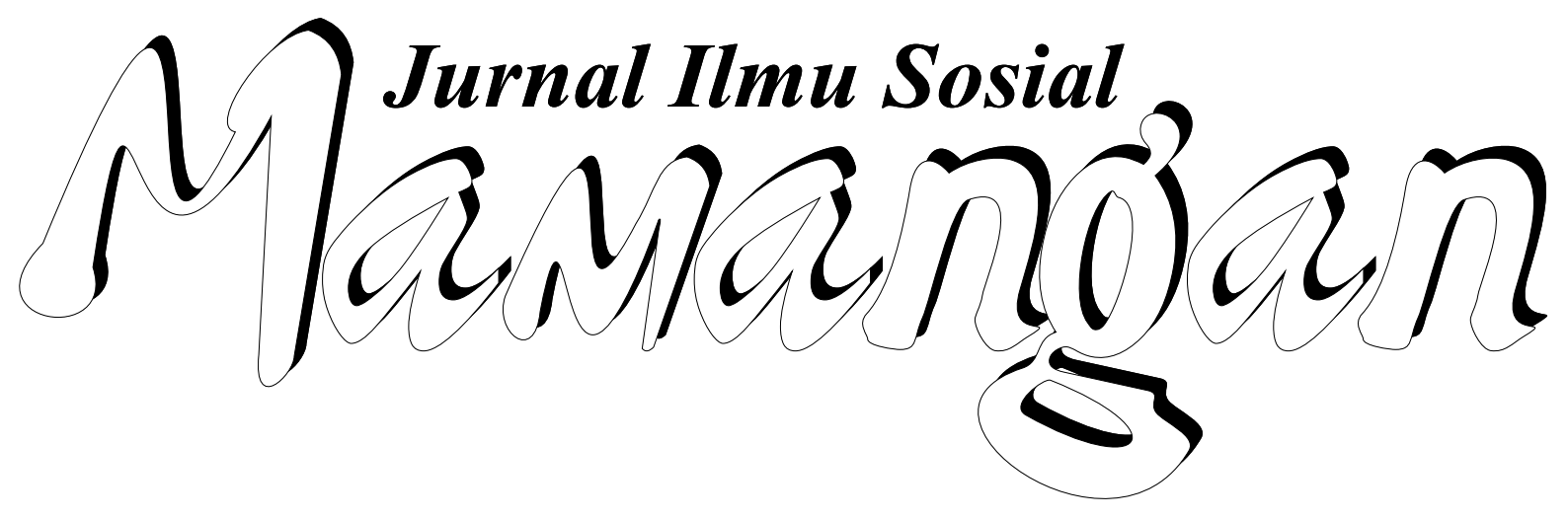




\section{一挑一 \\ Jurnal Ilmu Sosial Mamangan}

Volume 2, Nomor 1, Januari-Juni 2015

\section{Mitra Bestari}

Prof. Dr. Afrizal, MA. (FISIP, Unand Padang)

Prof. Dr. Badaruddin, M. Si. (FISIP, USU Medan)

Dr. A. Latief Wiyata, M. Si. (Universitas Jember, Jember)

Dr. Fikarwin Zuska, M. Si. (FISIP, USU Medan)

Nurus Shalihin, M. Si., Ph.D. (Fak. Ushuluddin IAIN Imam Bonjol Padang)

Dr. Semiarto A. Purwanto, M. Si. (FISIP, UI Jakarta)

Dr. Wahyu Wibowo, M. Si. (Universitas Nasional, Jakarta)

\section{Dewan Redaksi}

Dr. Zusmelia, M. Si.

Dr. Maihasni, M. Si.

Firdaus, S. Sos., M. Si.

\section{Pemimpin Redaksi/Editor}

Firdaus, S. Sos., M. Si.

\section{Anggota Redaksi}

Ariesta, M. Si.

Dian Kurnia Anggreta, S. Sos., M. Si.

Faishal Yasin, S. Sos., M. Pd.

Ikhsan Muharma Putra, M. Si.

Rio Tutri, M. Si.

Sri Rahayu, M. Pd.

Yuhelna, MA.

ISSN: 2301-8496

viii +109 halaman, $21 \times 29 \mathrm{~cm}$

\section{Alamat Redaksi:}

Laboratorium Program Studi Pendidikan Sosiologi, STKIP PGRI Sumbar Kampus STKIP PGRI, Jl. Gunung Pangilun, Padang, Sumatera Barat

Email: redaksimamangan@gmail.com \& daus_gila@yahoo.com

\section{Penerbit:}

Laboratorium Program Studi Pendidikan Sosiologi, STKIP PGRI Sumbar 


\section{PENGANTAR REDAKSI}

$\mathrm{K}$

ebudayaan merupakan produk yang dihasilkan oleh manusia, baik dalam bentuk ide, tindakan maupun karya. Yang terakhir disebut merupakan produk kebudayaan yang paling kongkrit dan termati dalam masyarakat. Kebudayaan terus diproduksi oleh manusia sesuai dengan zaman dan tantangannya untuk memenhi kebutuhan hidup mereka saat itu. Oleh karena kebudayaan terus diprosukdi oleh manusia, maka kebudyaan terus berdinamika sesuai dengan ruang dan waktu. Proses dinamika tersebut kadang berjalan dengan lambat dan kadang berjalan dengan cepat.

Respon terhadap dinamika kebudayaan juga berbeda berdasarkan kelompok. Paling tidak terdapat tiga kelompok berbeda menurut redaksi dalam menanggapi dinamika kebudayaan. Kelompok pertama adalah kelompok yang resah dengan dinamika kebudayaan, kedua kelompok yang senang dengan dinamika dan ketiga kelompok yang berada pada titik keseimbangan dalam melihat dinamika kebudayaan. Terlepas dari tiga kelompok yang ada, redaksi menyadari bahwa dinamika kebudayaan pasti akan berlangsung kapan saja dan dimana saja. Oleh karenanya, banyak bentuk kebudayaan baru yang dihasilkan dan banyak kebudayaan lama ditinggalkan.

Menyadari bahwa proses dinamika kebudayaan akan menghasilkan bentuk kebudayaan yang baru dan kebudayaan lama ditinggalkan, pada edisi ini redaksi mengambil tema-tema tulisan menyangkut kebudayaan. Tulisan-tulisan yang ada bicara dalam tema kebudayaan dengan berbagai perspektif dan pendekatan. Pendekatan itu mulai dari sejarah, hingga perlawanan, sehingga tulisan-tulisan dalam edisi ini disumbangkan oleh mereka dengan latar belakang yang berbeda.

Tulisan pertama disumbangkan oleh Prof. Heddy Shri Ahimsa-Putra, Guru Besar UGM. Dalam tulisannya Ahimsa-Putra menguraikan seni tradisi di Indonesia. Menurutnya terdapat tiga seni tradisi di Indonesia, yaitu seni tradisi Ageng, seni tradisi Alit dan seni tradisi suku. Seni-seni tradisi tersebut memiliki fungsi sebagai atraksi wisata, sebagai jati diri komunitas dan sebagai sumber inspirasi untuk penciptaan dan pengembangan seni-seni baru. oleh karenanya, 
seni tradisi tersebut perlu dilestarikan dan dikembangkan. Pelestarian dan pengembangan seni tradisi di Indonesia saat ini terkendala oleh banyak hal. Dalam tulisannya, Ahimsa-Putra menawarkan beberapa alternatif yang dapat dilakukan untuk pelestarian dan pengembangan seni tradisi.

Tulisan kedua ditulis oleh Silvia Delvi, Peneliti Balai Kajian Sejarah Sumatera Barat. Devi dalam artikelnya membahas tentang songket sebagai produk kebudayaan di nagari Pandai Sikek Sumatera Barat. Dalam tulisannya, Delvi lebih menekan pada aspek sejarah dan nilai songket di Pandai Sikek. Menurutnya, Songket Pandai Sikek sudah ada sejak pertengahan abad ke-19. Proses produksi songket Pandai Sikek sangat eksklusif untuk warga Pandai Sikek dan tidak ditransfer kepada orang lain. Hal ini karena terdapat rahasia pembuatan dan nilai pada masing-masing motif yang diproduksi. Jika ingin pandai menenun songket Pandai Sikek, satu-satunya cara adalah dengan menjalin hubungan keluarga dengan orang Pandai Sikek.

Tulisan berikutnya ditulis oleh Meri Erawati, Dosen Sejarah STKIP PGRI Sumbar. Erawati menulis cerita nonton bioskop pada tempo dulu di Kota Padang. Dalam tulisannya, Erawati membahas tentang perkembangan bioskop dan jenis film yang ditayangkan di Kota Padang pada era 1970-2000. Yang menarik dari uraian Erawati adalah cerita tentang bagaimana simbol-simbol muncul di seputaran bioskop dan kecenderungan style orang-orang menonton bioskop pada masa itu. Tidak terkecuali itu, temuan Erawati tentang kejahilan-kejahilan penonton terhadap penonton lainnya memperkaya tulisan Erawati.

Tulisan keempat ditulis oleh Silfia Hanani, dosen Sosiologi IAIN Bukittinggi. Hanani menulis tentang batu akik yang sangat popular dan booming beberapa waktu belakangan. Dalam tulisannya, Hanani menguraikan bagaimana nalar individu dipengaruhi oleh nalar kolektif tentang batu akik, dampaknya semua orang-minimal- memperbincangkan batu akik. Lebih dalam, Hanani juga membahas pemaknaan orang terhadap batu akik yang mengalami pergeseran dari pemaknaan yang sakral ke pemaknaan keindahan dan seni. Masing-masing jenis batu kemudian menjadi identitas bagi penanda bagi daerah asal dimana batu akik ditemukan. Di bagian lain, Hanani juga mendiskusikan paradoks batu akik dengan persoalan kehidupan dan lingkungan.

Tulisan kelima ditulis oleh Faishal Yasin, Dosen Sosiologi STKIP PGRI Sumbar. Tulisan Yasin membahas tentang gaya yang diampilkan oleh remaja di hiburan malam seperti café, bilyar dan diskotik. Secara detail Yasin menguraikan bagaimana para remaja berpakaian, memilih makanan dan musik di masing-masing lokasi hiburan. Yasin kemudian menghubungkan gaya tersebut dengan kultur induk -Minangkabau- dimana remaja tersebut hidup dan berkembang. Dalam analisisnya, Yasin menyebutkan bahwa gaya tersebut merupakan penyimpangan dari kultur induk mereka.

Tulisan keenam ditulis oleh Yusar, dosen Sosiologi Universitas Padjajaran. Yusar menulis perlawawan anak muda terhadap hegemoni radikalisme anak muda di tiga kota di Indonesia. Temuan Yusar, perkembangan tekhnologi dimanfaatkan oleh anak muda secara kreatif dalam melakukan perlawanan terhadap radikalisme agama di tiga kota tersebut. Anak muda menggunakan berbagai media berbasis tekhnologi untuk mengekspresikan perlawanan 
mereka. Ekspresi tersebut anatara lain mereka representasikan melalui meme, pelesetan kata dan lain sebagainya. Dengan baik Yusar kemudian menampilkan berbagai meme dan plesetan kata serta maknanya dalam artikelnya yang cukup panjang.

Tulisan terakhir ditulisn oleh Darmairal Rahmad, dosen sosiologi STKIP PGRI Sumatera Barat. Rahmad menulis integrasi dan interaksi anak muda rantau (kasus mahasiswa) di kawasan kost-kostan kota Padang. Dengan mengambil setting di kawasan Air Tawar Barat, Rahmad menemukan berbagai model dan tipologi interaksi dan ientegrasi anak muda dengan masyarakat di sekitarnya berdasarkan empat pola. Yang menarik dari tulisan Rahmad selain data yang kaya adalah pola penyajian data kualitatif dalam bentuk matrik probabilitas. Sebuah pola yang unik dalam penyajian tulisan kualitatif secara dalam bentuk matrik. Bisa jadi, ini akan menjadi model baru dalam metode penelitian yang kini sedang berkembang, yaitu mixed method.

Demikianlah para penulis telah menymbangkan buah fikiran mereka dalam edisi ini yang tentu saja dapat dibaca secara lebih mendalam pada setiap judul tulisan. Redaksi hanya mengantarkan pembaca pada kulit dari apa yang ditulis oleh para penulisn. Untuk lebih mendalam pada bagian isi, redaksi mengucapkan selamat membaca.

Redaksi 



\section{DAFTAR ISI}

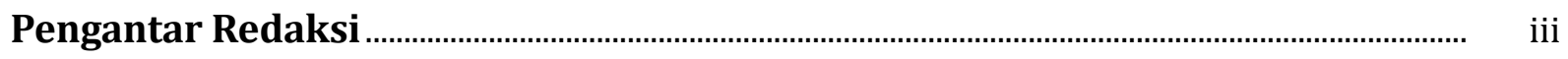

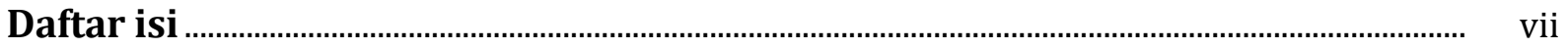

Seni Tradisi, Jatidiri dan Strategi Kebudayaan

Heddy Shri Ahimsa-Putra

Sejarah dan Nilai Songket Pandai Sikek

Silvia Devi

Budaya dalam Lintasan Sejarah: Booming Nonton Bioskop di Padang Tempo Dulu

Meri Erawati.

Paradoksal Gaya Sosial Global; Kajian Budaya dalam Memahami Kesadaran Kolektif di Tengah Booming Batu Akik

Silfia Hanani.

Gaya Kehidupan Malam Remaja di Kota Padang; Suatu Kajian Subkultur di Tempat Hiburan Malam Kota Padang

Faishal Yasin.

Perlawanan Kaum Muda terhadap Hegemoni Radikalisme Agama dalam Bentuk-Bentuk Budaya Populer

Yusar

Gaya Interaksi \& Integrasi Sosial Anak Muda Rantau: Kasus Mahasiswa Kost di Air Tawar Barat, Kota Padang

Darmairal Rahmad.

Profil Penulis 


\title{
PERLAWANAN KAUM MUDA TERHADAP HEGEMONI RADIKALISME AGAMA DALAM BENTUK-BENTUK BUDAYA POPULER
}

\author{
Yusar \\ yuzzsar@gmail.com \\ Dosen Program Studi Sosiologi, Fakultas Ilmu Sosial dan Ilmu Politik \\ Universitas Padjadjaran, Bandung \\ 一恝-
}

\begin{abstract}
This paper aim to describe the middle class youth resistance against the religion radicalism which hegemonized the society. Religion radicalism is one of the main issue faced by the Indonesian as their cause of the communal conflicts within the state. The youths are the main target of the spreading the radicalism ideology. The qualitative method was done to comprehend the meanings of the middle class youth contemporary popular culture. Data was gained by several observation, depth interview, and framing analyses to the actors who are made the resistance. The results found that the youth have an awareness of the religion radicalism hegemony and made the resistance against the radicalist with several communicatively artistic appearance and oftten ironics which constructing the forms of youth contemporary popular culture.
\end{abstract}

Keywords: resistance, youth popular culture, religion radicalism

Artikel ini bertujuan menggambarkan perlawanan kaum muda kelas menengah terhadap radikalisme agama yang mereka anggap menghegemoni masyarakat saat ini. Radikalisme agama merupakan salah satu isu utama yang dihadapi oleh bangsa Indonesia karena dapat menjadi pemicu terjadinya konflik pada unsur masyarakat di Negara Indonesia. Kaum muda menjadi sasaran utama penyebaran ideologi radikal. Metode kualitatif dilakukan untuk memahami makna-makna yang tertampil dalam budaya populer kaum muda keas menengah. Pengumpulan data dilakukan melalui serangkaian pengamatan, wawancara, dan analisis framing terhadap para aktor-aktor yang melakukan perlawanan terhadap gerakan radikalisme agama tersebut. Ditemukan bahwa kaum muda memiliki kesadaran atas hegemoni radikalisme agama dan menyusun suatu perlawanan terhadap kaum radikal melalui serangkaian tampilan komunikasi yang artistik dan seringkali mengandung unsur ironi yang dibangun dalam bentuk-bentuk budaya populer kontemporer kaum muda .

Kata kunci: perlawanan, budaya populer kaum muda, radikalisme agama 


\section{LATAR BELAKANG}

Radikalisme agama bukan sebuah gerakan baru dalam sejarah bangsa Indonesia. Gerakan radikalisme agama di masa lalu dan masa sekarang memiliki persamaan yakni untuk membebaskan umat dari penjajahan. Perbedaannya adalah pada lawan yang dihadapi. Bruinessen (2002: 117) menyatakan bahwa sejarah Indonesia diwarnai oleh gerakangerakan radikal keagamaan. Pada masa lalu gerakan radikal keagamaan berhadapan dengan lawan yaitu penjajah kolonial, pada masa sekarang lawan yang dihadapi oleh gerakan radikal adalah pihak yang berbeda paham dengan mereka dan dianggap menjajah. Perbedaan lainnya adalah pada masa prakemerdekaan, gerakan keagamaan lahir dari tekanan penjajahan, pada masa kini, gerakan radikal lahir dan tumbuh karena kebebasan. Kebebasan yang dimaksud adalah terbukanya katup-katup demokrasi pasca berakhirnya rezim Orde Baru yang dipimpin oleh Suharto (Bruinessen, 2002; Vatikiotis, 2003, Kingsbury, 2003, Henley dan Davidson, 2007; Woodward, 2011; Munip, 2012).

Pada masa Orde Baru, gerakan keagamaan mendapatkan tekanan kuat alihalih untuk stabilitas negara melalui jargon Suku, Agama, Ras, dan Antar golongan (Brown, 2005: 8). Pada tahun 1980an, terjadi pergeseran yakni saat para kaum muda terpelajar diberi peluang untuk mengenyam pendidikan di negara-negara Timur Tengah, terutama Mesir. Dari kaum muda tersebut, muncul gerakangerakan revivalisme agama melalui kampuskampus yang umumnya berada di Jawa. Bibitbibit gerakan radikalisme pada golongan Islam digagas oleh para kaum muda terpelajar dan menjadikan kampus-kampus sebagai pusat aktivitas gerakannya. Radikalisme di kalangan kaum muda terpelajar tersebut diilhami oleh
Revolusi Iran tahun 1979 (Bruinessen, 2002).

Memaknai hasil penelitian Bruinessen (2002), kampus-kampus baik sekolah maupun perguran tinggi tidak kedap terhadap pahampaham radikal. Aktivis-aktivis gerakan radikal Islam, setelah mereka lulus dapat berprofesi sebagai pengajar, baik guru maupun dosen. Dari para guru dan dosen bekas aktivis gerakan radikal tersebut paham radikal ditransmisikan kepada siswa atau mahasiswa. Di sisi lain, kampus merupakan salah satu arena tempat kaum muda menjalankan aktifitasnya. Hal ini menyiratkan bahwa kaum muda berada dalam arena di mana paham-paham radikalisme agama ditransmisikan dari generasi di atas mereka. Mengacu pada Ahnaf (2013: 155), bagi sebagian pihak kaum muda, termasuk remaja yang masih duduk di bangku sekolah menengah, adalah salah satu segmen masyarakat yang paling rentan terpengaruh ideologi radikal.

Kenyataan bahwa Indonesia merupakan bangsa multikultur, tidak seluruh kaum muda mendukung paham radikalisme agama. Sebagian kaum muda terpelajar menganggap bahwa paham radikalisme agama kini telah menghegemoni kaum muda. Golongan kaum muda ini melakukan resistensi dengan gaya khas kaum muda terhadap kaum radikal. Resistensi dilakukan dalam bentuk budaya populer kontemporer khas kaum muda.

Dalam menanggapi fenomena radikalisme agama di Indonesia, kaum muda melakukan reaksi berupa perlawanan dengan cara mereka sendiri. Seperti yang dinyatakan Hebdige (1979), Bennet (2002, 2006), Hodkinson (2007), kaum muda sebagai kategori sosial memiliki cara sendiri dalam perlawanan terhadap radikalisme agama sebagai bentuk peneguhan identitasnya. Mengacu pada Tittley (1999) melalui serangkaian bakat artistik yang tertampil dalam komunikasi visual kaum 
muda membentuk ruangan-ruangan kekuatan yang berkontradiksi dengan pihak atau paham yang dianggap menghegemoni mereka. Praksis budaya mereka dikenal dan diakui oleh masyarakat budaya dominannya dan dari pengakuan tersebut memberi kekuatan bagi mereka untuk bertindak. Proses selanjutnya adalah pada pengakuan identitas sebagai pihak yang melawan radikalisme agama.

Perlawanan khas kaum muda terhadap radikalisme agama menguat saat gerakan militant Islamic State Of Iraq and Suriah (ISIS) mengemuka dan juga saat Pemilihan Presiden (pilpres) Republik Indonesia Tahun 2014. Kaum muda yang menentang radikalisme agama secara kreatif menyusun serangkaian perlawanan dalam bentuk komunikasi visual dan komunikasi verbal yang bersifat satir, parodi, dan ironi. Dalam hal ini, kaum muda dapat dipandang secara aktif sebagai produsen budaya, menanggapi kondisi lingkungan di sekitarnya karena waktu senggang yang dimilikinya relatif lebih banyak dibandingkan kelompok lainnya (Hendry et al, 2005). Komunikasi visual dan verbal yang dikembangkan oleh kaum muda sebagai bentuk perlawanan terhadap radikalisme agama senada dengan Brake (1985:12), yakni kaum muda menciptakan dan menyebarluaskan bahasa/dialek suatu kosakata yang unik yang dapat diterima sebagai penegasan posisi mereka dalam pertarungan memperebutkan ruangan-ruangan budaya.

Mengacu pada pada Hall (1996a; 1996b), perlawanan kaum muda terhadap radikalisme agama membentuk arena konsensus dan sekaligus resistensi dalam memperjuangkan makna-makna kultural. Dalam arena yang terbentuk, terdapat perselisihan nilai-nilai politis dan nilai-nilai kultural. Pada arena inilah berdasarkan resistensi yang dibangun, fenomena hegemoni radikalisme agama pada golongan kaum muda ditentang oleh kaum muda kelas menengah terpelajar melalui serangkaian tindakan kreatif. Berkaitan dengan hal tersebut, mengacu pada Hall (1996a; 1996b) maka konsepsi politis budaya popular adalah sebagai arena memperjuangkan makna kultural melalui serangkaian kuasa-kuasa tindakan kreatif.

Artikel ini membahas bentuk budaya populer kaum muda dalam menghadapi hegemoni gerakan radikal keagamaan. Pembahasan juga mencakup kreativitas kaum muda dalam menampilkan bentuk perlawanan yang artistik dan terkadang menampilkan ironi sambil menegaskan identitas mereka sebagai kaum muda yang memproduksi budaya, khususnya budaya populer.

\section{TINJAUAN PUSTAKA}

Perlawanan kaum muda terhadap hegemoni radikalisme agama sangat sulit ditemukan atau jarang ditinjau oleh para ahli. Hal ini diasumsikan bahwa radikalisme agama lebih sering dilihat dari perspektif makro daripada perspektif mikro. Meskipun demikian, terdapat beberapa studi yang relevan untuk membahas radikalisme yang akan menjadi pembahasan dalam artikel ini.

Radikalisme agama dalam perspektif makro yang berkaitan dengan kaum muda telah ditinjau oleh Bruinessen (2002) yang menemukan bahwa radikalisme agama di Indonesia digagas oleh kaum muda terpelajar. Bruinessen (2002) menyatakan bahwa bibitbibit radikalisme agama di kalangan kaum muda terpelajar merupakan akibat kebijakan orde baru yang memberi kesempatan kepada para pelajar dan mahasiswa untuk menimba ilmu di negara-negara Timur-Tengah, seperti 
Mesir, Jordania, atau Arab Saudi. Di negaranegara tersebut, kaum muda mempelajari gerakan-gerakan islam radikal seperti gerakan Ikhwanul Muslimin atau Hizbut Tahrir. Secara paralel, kaum muda Indonesia dalam jumlah yang relatif besar juga turut menjadi relawan perlawanan perjuangan rakyat Afganistan dalam melawan Uni Sovyetkomunis. Komunisme pada masa orde baru merupakan musuh terbesar yang harus dilawan. Perlawanan terhadap komunisme pada masa itu mencapai titik tertinggi dengan diberlakukannya stigma terhadap mereka yang dianggap sebagai pendukung atau partisan komunis.

Abuza (2007) meneliti mengenai gerakan radikal di kalangan kaum muda. Sebagian kaum muda terpelajar seperti siswa atau mahasiswa terpengaruh oleh paham radikal keagamaan. Kaum muda ini bercirikan 1) intoleran terhadap perbedaan; 2) mudah mengkafirkan pihak lain; 3) ketaatan kaku terhadap pemimpinnya: 4) berupaya menguasai ruang politik kampus; 5) mendukung tindak kekerasan yang dilakukan oleh kaum radikal.; dan 6) mengacu pada Abuza (2007: 66), kaum muda ini melakukan berbagai bentuk perlawanan terhadap pemerintahan yang dianggap sekuler dan menyimpang dari agama, menentang dan berusaha mengubah dasar negara Republik Indonesia, yakni Pancasila dengan azas-azas atau paham yang mereka yakini. Secara ringkas, tersaji dalam tabel 1 di bawah. Karakteristik kaum muda radikal menurut Abuza dapat dilihat padda tabel berikut:

Tabel 1

Karakteristik Kaum Muda Gerakan Radikal

\begin{tabular}{|c|c|c|}
\hline No & Ciri & Keterangan \\
\hline 1 & $\begin{array}{l}\text { Intoleran terhadap } \\
\text { perbedaan }\end{array}$ & $\begin{array}{l}\text { - Menafikan keberagaman yang ada di } \\
\text { sekitarnya dan memaksakan budaya mereka } \\
\text { kepada kelompok lain. } \\
\text { - Budaya yang disandang oleh kaum muda } \\
\text { berpaham radikal diadopsi dari budaya } \\
\text { timur-tengah dan menolak budaya-budaya } \\
\text { lain, meskipun budaya tersebut berakar dari } \\
\text { lokalitas masyarakat }\end{array}$ \\
\hline
\end{tabular}

\begin{tabular}{|c|c|c|}
\hline 2 & Mudah mengkafirkan & $\begin{array}{l}\text { - Cenderung mudah menyematkan istilah } \\
\text { kafir kepada kelompok yang berbeda dengan } \\
\text { mereka. } \\
\text { - Segala tingkah laku yang berbeda dengan } \\
\text { kelompoknya diberi label kafir } \\
\text { - Perilaku di luar kelompoknya adalah hasil } \\
\text { dari konspirasi barat-yahudi-zionisme }\end{array}$ \\
\hline 3 & $\begin{array}{l}\text { Ketaatan kaku terhadap } \\
\text { pimpinan }\end{array}$ & $\begin{array}{l}\text { - Sangat taat dan patuh terhadap pemimpin di } \\
\text { dalam kelompok } \\
\text { - Taat dan patuh terhadap pemimpin politik di } \\
\text { luar kelompok yang menaungi kelompoknya. } \\
\text { - Mengarah pada tindakan pengkultusan } \\
\text { pribadi ataupun pengkultusan kelompok }\end{array}$ \\
\hline 4 & $\begin{array}{l}\text { Penguasaan ruang } \\
\text { politik kampus }\end{array}$ & $\begin{array}{l}\text { - Menguasai lembaga-lembaga siswa atau } \\
\text { mahasiswa seperti Badan Eksekutif } \\
\text { Mahasiswa (BEM), Bapan Perwakilan } \\
\text { Mahasiswa (BPM), OSIS, atau lembaga } \\
\text { ekstrakurikuler } \\
\text { - Upaya memperlancar rekrutmen dan } \\
\text { menjalankan agenda-agenda gerakan radikal } \\
\text { yang dikendalikan dari luar kampus atau } \\
\text { sekolah }\end{array}$ \\
\hline 5 & $\begin{array}{l}\text { Mendukung tindak } \\
\text { kekerasan berdasarkan } \\
\text { agama }\end{array}$ & $\begin{array}{l}\text { - Tindakan kekerasan berdasar agama } \\
\text { merupakan upaya untuk menertibkan } \\
\text { masyarakat } \\
\text { - Tindakan kekerasan merupakan perintah } \\
\text { Tuhan melalui kitab suci untuk memerangi } \\
\text { segala bentuk tindakan-tindakan yang } \\
\text { dianggap berlawanan dengan aturan agama. } \\
\text { - Dukungan terhadap tindakan terorisme } \\
\text { - Dukungan terhadap peperangan bersenjata } \\
\text { terhadap pihak-pihak yang dianggap musuh } \\
\text { Tuhan } \\
\end{array}$ \\
\hline 6 & $\begin{array}{l}\text { Perlawanan terhadap } \\
\text { pemerintah }\end{array}$ & $\begin{array}{l}\text { - Pemerintahan yang dianggap sekuler dan } \\
\text { menyimpang dari agama } \\
\text { - Menentang dan berusaha mengubah dasar } \\
\text { negara }\end{array}$ \\
\hline
\end{tabular}

Hasil survay Lembaga Kajian Islam dan Perdamaian (LaKIP) ${ }^{1}$ yang dilaksanakan pada tahun 2010 hingga 2011 menunjukkan bahwa 49\% siswa bersikap setuju terhadap aksi radikal terhadap agama. Radikalisme agama tidak hanya sebatas pada siswa. Golongan mahasiswapun memiliki kecenderungan mendukung gerakan radikal atas nama agama. Dari 2.466 responden mahasiswa, sebanyak 1.594 responden (65\%) menyetujui tindakan sweeping kemaksiatan, sebanyak 446 responden (18\%) mendukung dan terlibat aktif dalam kegiatan sweeping kemaksiatan, 268 responden (11\%) tidak menyetujui kegiatan sweeping kemaksiatan, dan 158 responden (6\%) tidak memberikan jawaban. Lebih lanjut, sebanyak 2.170 responden (88\%) menyatakan bahwa kegiatan sweeping tersebut merupakan perintah agama. Berdasarkan data di atas, kaum muda merupakan golongan yang tidak

1. (www.swatt-online.com/2011/04/lakip-pemerintah-harustinjau-kembalipendidikan-agama-islam/. Diakses tanggal 15 Mei 2015) 
kedap terhadap paham radikal. Demikian pula dengan institusi pendidikan, seperti kampus pendidikan tinggi maupun pendidikan tingkat di bawahnya (SMA, SMP, atau SD).

Argumen bahwa kaum muda menjadi agen gerakan radikal keagamaan dinyatakan oleh Azca (2011) dengan pendekatan psikologi perkembangan yang disandang oleh kaum muda. Kaum muda sebagai fase transisi ditandai dengan pembukaan kognitif, sebuah proses mikrososiologis yang mendekatkan kaum muda terhadap gagasan baru yang lebih radikal. Pada usia muda, umum ditemui adanya ketergoncangan moral yaitu gejala saat seseorang menemukan bahwa moralitas yang terjadi dalam masyarakat bertentangan dengan gagasan baru yang ia terima, dalam konteks ajaran radikal. Azca (2011) mengetengahkan bahwa kaum muda radikal merupakan aksi identitas yang dipicu oleh perubahan rezim yang terjadi dan membuka katup-katup demokrasi yang sebelumnya tersumbat. Kaum muda masuk menjadi agen dari kelompok radikal berdasarkan proses mikrososiologis yang diawali oleh krisis identitas lalu pembukaan kognisi dan ketergoncangan moral. Proses berikutnya adalah menjadi bagian dari gerakan radikal sebagai aksi identitas. Kaum muda saat ini mudah mengakses berbagai informasi dalam sebuah jejaring sosial. Jejaring sosial yang dimaksud oleh Azca (2011) tidak semata hubungan antar aktor kongkret tetapi juga jejaring sosial sebagai realitas fenomenologis dan jejaring makna. Konsep jaringan menjadi sangat penting karena dalam dalam sebuah jaringan terdapat transmisi makna. Melalui pemaknaan bersama, emosi mengalir dan dialami oleh kaum muda. Dari hal tersebut ideologi diterima oleh kaum muda. Adapun afiliasi dari ideologi yang diserap oleh kaum muda dapat berupa ideologi yang bersifat afiliasi eksklusif dan afiliasi majemuk. Pada kaum muda berpaham radikal, afiliasinya bersifat ekskulif, hanya berafiliasi pada kelompoknya saja.

Studi Salim, Kaelani, dan Azekiyah (2011) di 3 (tiga) sekolah menengah atas favorit di Yogyakarta menemukan bahwa gerakan radikal keagamaan yang intoleran terejawantah dalam lingkungan sekolah. Dalam penelitian tersebut, terjadi segregasi di antara para pelajar pendukung paham radikal keagamaan dengan pelajar lainnya. Di sekolah-sekolah tesebut terjadi dominasi dalam ruang publik yang dipelopori oleh kelompok ekstrakurikuler Kerohanian Islam (rohis). Rohis-rohis yang terdapat dalam sekolah-sekolah yang diteliti secara struktur sama kedudukannya dengan ekstrakurikuler lainnya, namun hubungan dan jaringan politik mereka dengan gerakangerakan di luar sekolah menjadikan agenda, kegiatan, dan tujuan rohis-rohis tersebut lebih bersifat politis-ideologis, jauh melampaui tujuan kelembagaan ekstrakurikuler yang digariskan oleh sekolah. Pola rekrutmen pelajar untuk ikut dalam gerakan islam radikal dimulai dari Masa Orientasi Sekolah (MOS) yang dilanjutkan dengan mentoring. Dalam penelitian tersebut, para alumni sekolahsekolah yang diteliti memberikan kontribusi yang sangat besar dalam menghimpun pelajar yang akan dijadikan sebagai pelanjut gerakan dengan menyusun suatu cita-cita sekolah darussalam, menguasai struktur lembagalembaga siswa sekolah seperti OSIS, MPK, dan juga dominasi rohis dalam ruang publik sekolah. Selanjutnya penelitian tersebut menemukan segregasi antara "tegel putih" yang berpaham radikal dengan "tegel merah" yang lebih mengedepankan sebagai siswa sekolah menengah negeri seperti umumnya. Seperti yang dinyatakan oleh Azca (2011), secara 
maknawi, ruangan tersebut menyatakan afiliasi dari kelompok radikal yaitu afiliasi eksklusif yang menjadi pembatasan antara "kami" dan "mereka". Salim, Kaelani, dan Azekiyah (2011) memaknai bahwa pada ruangan yang dibatasi oleh tegel berwarna putih dengan tegel berwarna merah terjadi kontestasi politik kehidupan sekolah dan terjadi resistensi simetris terhadap dominasi siswa berpaham keagamaan kaku oleh siswa lain yang berada di luar dominasi rohis.

Penelitian tentang budaya populer kaum muda telah banyak dilakukan oleh para hali sosial, khususnya teoretisi studi-studi budaya. Hebdige (1979) menyatakan bahwa subkultur punk merupakan suatu bentuk perlawanan kaum muda terhadap hegemoni melalui makna-makna yang tertampil dalam gaya-gaya yang ditunjukkan secara visual. Bennet (2007) menemukan bahwa kaum muda tidak semata diukur dalam hitungan usia, melainkan suatu kategori sosial yang memiliki cara hidup sendiri yang kreatif dalam suatu masyarakat yang lebih besar. Cara hidup yang kreatif tersebut seringkali bertentangan dengan nilai-nilai yang lebih umum atau bahkan dapat menjadi simbol sebuah pergerakan melawan suatu hal yang dianggap menghegemoni kehidupan masyarakat. Perbedaan yang ditunjukkan oleh kaum muda dalam menanggapi realitas sosial dan pengetahuan mereka atas dunia menjadikan kaum muda sebagai bagian yang berbeda dari suatu golongan budaya atau dinyatakan sebagai subkultur (Hebdige, 1979; Bennet, 2002, 2006, Hodkinson, 2007).

Penelitian Tittley (1999) mengenai kehidupan kaum muda memaparkan bahwa komunikasi visual adalah hal pertama yang dapat dilihat dan bahasa mengikuti pada arti-arti komunikasi visual tersebut. Sebagai contoh dapat dilihat pada pemain skateboard, penari jalanan, atau seniman graffiti yang berkomunikasi melalui gerakan atau gestur. Kelompok-kelompok tersebut merupakan kelompok yang memiliki "kekuatan" oleh ruangan-ruangan yang mereka bentuk melalui penampilan secara visual. Produksi budaya mereka dikenal dan diakui oleh masyarakat budaya dominannya dan dari pengakuan tersebut memberi kekuatan bagi mereka untuk bertindak. Proses selanjutnya adalah pada pengakuan identitas diri. Kontrol masyarakat dibentuk melalui penampakan visual atas bakat kreatif mereka. Menurut Brake (1985), bahwa gaya atau style terdiri atas tiga elemen, yaitu 1) kesan penampakan yang tersusun oleh kostum, asesori-asesori seperti potongan rambut, perhiasan, ornamen-ornamen badan; 2) sikap yang terbangun dari ekspresi, gaya berjalan, dan postur; 3) bahasa/dialek suatu kosakata yang unik dan bagaimana hal ini disebarluaskan (Brake, 1985: 11-12).

Pada usia remaja, terjadi ketegangan atau kontradiksi diri mereka dengan orang tuanya dan juga merupakan masa penelusuran atau pencarian berbagai jenis identitas personal untuk membentuk indentitas dirinya. Pembentukan identitas diri merupakan suatu proses yang berlangsung selama hidup seorang individu, namun mengalami peningkatan, terutama pada usia remaja sebagai tahap awal kelanjutan bentuk-bentuk pengembangan psikososial seorang individu (Grotevant dan Copoper, 2005). Seringkali pembentukan identitas dilihat sebagai pengujian atau pencarian atas berbagai peluang atau kesempatan yang ditemui oleh kaum remaja. Saat berada pada usia remaja, seorang individu dapat terlibat dalam berbagai aktivitas, mencoba peran dan gaya hidup yang baru, serta berinteraksi dengan individuindividu lain di luar lingkungan orangtua atau 
keluarganya (Hendry et al, 2005). Berbagai aktivitas tersebut memungkinkan bagi individu untuk mengindentifikasi dan membandingkan identitas dirinya dengan individu lain dalam hubungan sosial. Secara sosiologis, paham radikal ditransmisikan secara antar generasi dengan target utamanya adalah kaum muda. Kelak kaum muda saat ini akan menjadi agenagen gerakan radikal keagamaan.

\section{METODE}

Artikel ini merupakan bagian dari penelitian mengenai radikalisme agama dan kaum muda. Penelitian dilakukan di 3 (tiga) kota, yakni Bandung, Depok, dan Jakarta selama bulan April 2014 hingga Februari 2015 dengan metode kualitatif. Pengumpulan data dilakukan melalui serangkaian pengamatan atas tindakan-tindakan kreatif kaum muda dalam menanggapi radikalisme agama yang terjadi di tiga kota tersebut. Wawancara secara mendalam kepada individu-individu kaum muda berpaham radikal dan non-radikal dilakukan untuk mendapatkan hal yang tidak dipahami dalam observasi atas tindakan budaya-tindakan budaya yang tertampil. Analisis framing digunakan untuk membingkai secara interpretif praksis budaya kaum muda sehingga bentuk-bentuk tindakan budaya kaum muda menjadi ajeg dalam bentuk budaya populer kaum muda.

\section{RADIKALISME AGAMA DI KALANGAN KAUM MUDA}

Perubahan iklim politik Indonesia yang semakin terbuka, menyebabkan paham radikal tumbuh subur. Sebagian golongan bangsa Indonesia menerima paham radikal sebagai alat pencapaian terbentuknya masyarakat yang dianggap ideal. Kondisi masyarakat yang ideal ini berbenturan dengan konsensus bangsa, yakni Pancasila. Golongan radikal menganggap bahwa dasar negara Indonesia adalah sistem buatan manusia, sehingga yang menjalankannya berarti menuhankan buatan manusia. Oleh karenanya, dalam istilah golongan radikal, setiap rezim yang berkuasa di Indonesia tidak memiliki dasar teologis yang kuat dan tidak berlandaskan pada nilai agama atau diistilahkan dengan sistem thagut.

Selain mengkritisi dasar negara, dalam kehidupan sehari-hari di dalam masyarakat, golongan radikal cenderung bersifat intoleran terhadap golongan yang berbeda dengannya. Istilah takfiriatau kelompok yang mengkafirkan pihak lain, disematkan kepada golongan radikal karena kerap mengkafirkan golongan yang berlainan dengan mereka. Tidak hanya umat agama lain, terhadap umat seagama pun jika berbeda haluan akan diberi label sebagai kafir liberal.

Kaum muda golongan radikal dicirikan dengan kepatuhan penuh terhadap pimpinannya tanpa mengkritisinya. Kaum muda golongan radikal bersikap intoleran terhadap perbedaan yang ada di sekitarnya. Dalam kehidupan kampus, golongan radikal tersebut berupaya memperoleh ruangan-ruangan politis, semisal mengusai mesjid kampus, acara keagamaan, ataupun menduduki posisi di badan eksekutif seperti Organisasis Siswa Intra Sekolah (OSIS) atau Badan Eksekutif Mahasiswa (BEM). Kaum muda golongan radikal dalam kesehariannya memiliki jaringan pertemanan yang homogen. Dari penelitian yang dilakukan, umumnya mereka tidak banyak terlibat dalam kegiatan-kegiatan kemasyarakatan di sekitarnya dan cenderung menarik diri dari aktivitas sosial kemasyarakatan. Dari perilaku yang ditunjukkan oleh kaum muda radikal, dapat dibingkai bahwa mereka cenderung 
menutup diri dari realitas plural masyarakat Indonesia.

Sebagian golongan kaum muda lainnya menganggap bahwa paham radikal keagamaan mengingkari kenyataan bangsa Indonesia yang multikultur. Sebagaimana kaum muda pendukung paham liberal, penentang paham radikal pun berasal dari golongan kelas menengah dan terpelajar. Hal ini memiliki makna bahwa golongan kaum muda kelas menengah adalah golongan kaum muda yang sangat dinamis. Kedua golongan ini saling mengkutub dan berada dalam posisi yang bertentangan satu sama lain. Dari serangkaian observasi dan wawancara, kelompok penentang paham radikal tidak memiliki masalah terhadap individu, kelompok, ataupun golongan yang religius selama tidak melakukan hal yang ekstrim seperti kekerasan, mengkafirkan pihak yang berbeda, dan melanggar tatanan konsensus masyarakat.

Konflik secara visual dan verbal seringkali terjadi antara dua golongan kaum muda tersebut. Dalam hal ini, golongan kaum muda yang menentang paham radikal mendapatkan label sebagai kafir, liberal, dan antek-antek asing oleh kaum muda golongan radikal. Konflik antara golongan kaum muda berpaham radikal maupun penentang paham radikal tidak berujung pada konflik fisik. Pertentangan pada kode-kode verbal antara kedua golongan kaum muda tersebut pada gilirannya ditanggapi dengan munculnya budaya populer kaum muda kontemporer oleh golongan kaum muda penentang paham radikal. Seturut dengan Hall (1996a), budaya populer yang muncul akibat konflik merupakan suatu arena memperjuangkan makna kultural melalui serangkaian tindakan kreatif kaum muda penentang paham radikal.
Fenomena gerakan bersenjata Islamic State Of Iraq and Syria (ISIS) menjadi awal dari menguatnya konflik antar golongan kaum muda. Kaum muda pendukung paham fundamental menganggap bahwa ISIS merupakan pahlawan-pahlawan perjuangan dalam menciptakan masyarakat dunia yang ideal. Sebaliknya kaum muda penentang paham radikal memandang bahwa ISIS telah melakukan kejahatan kemanusiaan. Saat gerakan ISIS menghilangkan banyak nyawa di Irak dan Suriah, para pendukung gerakan radikal menggeser pandangannya bahwa perjuangan mereka adalah membasmi kebatilan di muka bumi. Kaum muda penentang paham radikal tetap berpandangan bahwa gerakan ISIS melakukan kejahatan kemanusiaan. Kemudian ketika gerakan ISIS menghancurkan situs-situs sejarah masa lalu, pendukung paham radikal semakin menggeser pandangan mereka, bahwa ISIS merupakan konspirasi dari kaum kafir untuk menjatuhkan pihak tertentu. Secara konsisten, penentang paham radikal tetap berpandangan bahwa gerakan ISIS melakukan kejahatan kemanusiaan. Secara detail, pandangan tersebut dapat dilihat pada tabel di bawah.

Tabel 2

Pandangan Kaum Muda Pendukung Paham Radikal dan Pandangan Kaum Muda Penentang Paham Radikal Terhadap Fenomena Gerakan ISIS

\begin{tabular}{|c|c|c|}
\hline \multirow{2}{*}{$\begin{array}{l}\text { Tindakan } \\
\text { Gerakan ISIS }\end{array}$} & \multicolumn{2}{|c|}{ Pandangan } \\
\hline & $\begin{array}{l}\text { Kaum Muda Pendukung } \\
\text { Paham Radikal }\end{array}$ & $\begin{array}{l}\text { Kaum Muda Penentang } \\
\text { Paham Radikal }\end{array}$ \\
\hline Keberadaan ISIS & $\begin{array}{l}\text { Jihad guna membentuk } \\
\text { tatanan masyarakat yang } \\
\text { ideal }\end{array}$ & $\begin{array}{l}\text { Melakukan kejahatan } \\
\text { kemanusiaan }\end{array}$ \\
\hline $\begin{array}{l}\text { Tindakan } \\
\text { bersenjata } \\
\text { yang memakan } \\
\text { korban jiwa }\end{array}$ & $\begin{array}{l}\text { Membasmi kebatilan di } \\
\text { muka bumi }\end{array}$ & $\begin{array}{l}\text { Melakukan kejahatan } \\
\text { kemanusiaan }\end{array}$ \\
\hline $\begin{array}{l}\text { Menghancurkan } \\
\text { situs bersejarah }\end{array}$ & $\begin{array}{l}\text { Konspirasi kaum kafir } \\
\text { untuk menjatuhkan } \\
\text { suatu pihak }\end{array}$ & $\begin{array}{l}\text { Melakukan kejahatan } \\
\text { kemanusiaan }\end{array}$ \\
\hline
\end{tabular}

Sumber: observasi tahun 2014

Konflik semakin mengkristal saat penyelenggaraan Pemilu Presiden 2014. Kaum 
muda pendukung paham radikal berada di kubu salah satu calon presiden yang didukung oleh partai-partai berbasis agama. Kaum muda penentang paham radikal lebih bersifat cair, ada yang mendukung calon presiden yang didukung oleh pendukung paham radikal, ada yang mendukung calon presiden lainnya, dan ada pula yang tidak mendukung keduanya. Dari pandangan kaum pendukung paham radikal, mereka yang tidak mendukung calon presiden yang didukungnya berarti berlawanan dengan mereka dan menganggap bahwa seluruh penentang paham radikal adalah pendukung calon presiden lawannya.

Melalui berbagai situs internet, kaum pendukung paham radikal menerima dan mempercayai informasi secara utuh dari situs-situs internet yang mendukung calon presiden pilihan mereka. Informasi-informasi yang disebarkan belum tentu kebenarannya dan dapat berupa kampanye negatif ataupun kampanye hitam, misalkan dengan menyertakan isu suku, agama, ras, dan antargolongan (SARA). Kaum muda pendukung paham radikal secara penuh mempercayai informasi-informasi yang diedarkan dari situssitus internet yang mendukung salah satu calon presiden pilihan mereka. Dari kubu penentang, mereka menilai bahwa kaum muda pendukung paham radikal tidak menyaring informasi yang diedarkan, tetapi menerima mentahmentah informasi tersebut. Karenanya, kaum muda penentang paham radikal beranggapan bahwa paham radikal telah menghegemoni secara masif kaum muda. Dari konflik tersebut, terbentuk perjuangan makna-makna kultural yang dilakukan oleh kaum muda penentang paham radikal sebagai bentuk perlawanan terhadap hegemoni paham radikal, khususnya di kalangan kaum muda.
Perjuangan makna-makna kultural ini menyebabkan kaum muda secara kreatif membangun perlawanan dalam bentuk komunikasi visual dan verbal. Komunikasi visual tersebut tertampil dalam bentuk-bentuk yang dapat dilihat secara umum baik secara langsung ataupun melalui media seperti internet. Komunikasi-komunikasi verbal dikembangkan dalam memberi label terhadap individu atau kelompok yang mendukung paham radikal dengan nuansa khas kreativitas kaum muda.

\section{KOMUNIKASI VISUAL: MEME}

Menanggapi fenomena paham radikal yang diterima oleh sebagian kaum muda, kaum muda penentang paham radikal memiliki kesadaran bahwa paham radikal telah menghegemoni sebagian dari kaum muda. Kaum muda penentang paham radikal menganggap bahwa kaum muda yang mendukung paham radikal telah terhegemoni dan menerima paham radikal sebagai sebuah konsensus yang harus dijalankan. Selain itu, kaum muda penentang paham radikal memiliki penilaian bahwa telah terjadi proses "cuci otak" terhadap kaum muda, sehingga mereka menjadi pendukung gerakan radikal dan bertindak intoleran terhadap perbedaan. Para kaum muda penentang paham radikal memandang bahwa paham radikal bukan menjalankan perintah agama secara radikal (mengakar) tetapi militansi mereka terhadap sifat dan sikap suatu kaum. Meski tidak mengklaim sebagai kaum nasionalis, kaum muda penentang paham radikal lebih melihat pada kenyataan plural dan berpegang pada ungkapan salah satu agama sebagai rahmat bagi seluruh alam semesta, tidak sekedar rahmat bagi satu golongan saja. 
Kaum muda penentang paham radikal melawan dengan tindakan membuat tampilan komunikasi visual yang dikenal sebagai meme (dibaca: mim). Meme bukan suatu hal yang baru dalam komunikasi visual kaum muda. Sebelumnya telah dikenal karikatur sebagai satir atau parodi dari suatu peristiwa. Perkembangan meme secara karikatural setidaknya telah dikenal melalui situs internet 9gag.com sejak akhir tahun 2000-an. Sebagai produk budaya kaum muda, meme digunakan untuk memparodikan satu kejadian. Melalui meme, artikulasi kode-kode bahasa tidak memerlukan narasi yang panjang melainkan relatif sederhana namun efektif dan tepat sasaran.

Sikap dan sifat kaum muda berpaham radikal dijadikan satir, parodi, dan ironi dalam bentuk meme. Komunikasi visual yang tertampil dalam meme kemudian disebarluaskan baik melalui media internet maupun dalam percakapan kaum muda keseharian. Produksi budaya dalam bentuk meme menjadi populer di kalangan kaum muda dan memiliki kekuatan politik untuk mempengaruhi kaum muda. Kekuatan politik yang terbentuk dalam arena perjuangan atas makna-makna budaya adalah bentuk perlawanan khas subkultur kaum muda terhadap hegemoni paham radikal. Hal ini seturut dengan Hebdige (1979) bahwa simbolsimbol yang dihasilkan oleh subkultur tidak dapat diabaikan kekuatan politiknya karena mampu mempengaruhi dan menggetarkan strukturnya yang lebih besar.

Tampilan visual meme yang bersifat satir, parodi, dan ironi menggambarkan kaum muda berpaham radikal mencerminkan halhal sebagai berikut: 1) kaum muda pendukung paham radikal yang memiliki sikap dan sifat ketimurtengahan daripada keagamaan; 2) kepatuhan kaku; 3) ketiadaan pemikiran kritis; dan 4) pemikiran sempit atas realita majemuk Indonesia. Gambaran tersebut dapat dilihat dalam tabel berikut.

Tabel 3

Komunikasi Visual Meme dalam Menganggapi Kaum Radikal

\begin{tabular}{|c|c|c|c|c|c|}
\hline No & Hal & Gambar & \begin{tabular}{|c|} 
Teks \\
Dalam \\
Gambar
\end{tabular} & $\begin{array}{c}\text { Sifat } \\
\text { Kalimat }\end{array}$ & Tujuan \\
\hline 1. & $\begin{array}{l}\text { Sikap dan } \\
\text { sifat ala } \\
\text { timur- } \\
\text { tengah }\end{array}$ & $\begin{array}{l}\text { 1. Karikatur } \\
\text { unta }\end{array}$ & Parodi & $\begin{array}{l}\text { Satir } \\
\text { dan } \\
\text { Parodi }\end{array}$ & $\begin{array}{l}\text { Perlawanan terhadap: } \\
\text { a. hegemoni budaya } \\
\text { timur tengah } \\
\text { b. timur tengah adalah } \\
\text { islam }\end{array}$ \\
\hline 2. & $\begin{array}{l}\text { Kepatuhan } \\
\text { kaku }\end{array}$ & $\begin{array}{l}\text { 1. Karikatur } \\
\text { kelompok } \\
\text { radikal } \\
\text { 2. Pemimpin } \\
\text { tokoh radikal }\end{array}$ & $\begin{array}{l}\text { Parodi } \\
\text { Parodi }\end{array}$ & $\begin{array}{l}\text { Parodi } \\
\text { dan } \\
\text { Ironi }\end{array}$ & $\begin{array}{l}\text { Penentangan terhadap: } \\
\text { a. tindakan kekerasan } \\
\text { yang dilakukan oleh } \\
\text { kelompok radikal } \\
\text { b. provokasi yang } \\
\text { dilakukan oleh tokoh } \\
\text { gerakan radikal }\end{array}$ \\
\hline 3. & $\begin{array}{l}\text { Ketiadaan } \\
\text { pemikiran } \\
\text { kritis }\end{array}$ & $\begin{array}{l}\text { 1. Karikatur } \\
\text { bedah } \\
\text { pengosongan } \\
\text { otak } \\
\text { 2. Teks } \\
\text { bertuliskan } \\
\text { huruf timur- } \\
\text { tengah }\end{array}$ & $\begin{array}{l}\text { Parodi } \\
\text { Ironi }\end{array}$ & $\begin{array}{l}\text { Parodi } \\
\text { dan } \\
\text { Ironi }\end{array}$ & $\begin{array}{l}\text { Perlawanan terhadap: } \\
\text { a. sikap dogmatis } \\
\text { b. mencocok-cocokkan } \\
\text { suatu kejadian tanpa } \\
\text { relevansi yang kuat } \\
\text { c. hegemoni budaya } \\
\text { timur tengah yang } \\
\text { dianggap sakral oleh } \\
\text { golongan radikal }\end{array}$ \\
\hline 4. & $\begin{array}{l}\text { Pemikiran } \\
\text { sempit atas } \\
\text { realitas } \\
\text { majemuk } \\
\text { bangsa } \\
\text { Indonesia }\end{array}$ & $\begin{array}{l}\text { 1. Tokoh paham } \\
\text { radikal } \\
\text { 2. Tokoh } \\
\text { nasional }\end{array}$ & $\begin{array}{l}\text { Parodi } \\
\text { Satir dan } \\
\text { Ironi }\end{array}$ & $\begin{array}{l}\text { Parodi } \\
\text { dan } \\
\text { Ironi }\end{array}$ & $\begin{array}{l}\text { Perlawanan terhadap: } \\
\text { a. sikap, pikiran, } \\
\text { dan tindakan } \\
\text { yang menafikan } \\
\text { keberagaman } \\
\text { masyarakat Indonesia } \\
\text { b. sikap mudah } \\
\text { mengkafirkan } \\
\text { golongan lain. } \\
\text { c. pengabaian atas } \\
\text { jasa para pahlawan } \\
\text { bangsa Indonesia }\end{array}$ \\
\hline
\end{tabular}

Sikap dan sifat kearab-araban digambarkan dengan wujud binatang unta yang diberi teks jenaka. Unta adalah hewan yang hanya hidup di gurun pasir yang identik dengan kondisi geografis Timur Tengah. Varian-varian dari visualisasi unta tersebut meliputi khasiat air seni unta sebagai bentuk keberatan dari kaum muda penentang paham radikal terhadap sikap kearab-araban yang ditunjukkan oleh kaum muda pendukung paham radikal. Kaum muda pendukung paham radikal berpandangan bahwa bersikap kearab-araban adalah sikap keagamaan. Di lain, sisi, kaum muda penentang paham radikal menganggap bahwa budaya kearab-araban tidak identik dengan sikap keagamaan. Bagi kaum muda penentang paham radikal, suatu 
hal yang datang dari wilayah Timur-Tengah tidak berarti sebagai hal yang spiritual-religius.

Kepatuhan kaku digambarkan dalam meme yang menampilkan hal berikut: a) kelompok radikal yang gemar melakukan tindakan kekerasan; dan b) pimpinan paham/ gerakan radikal. Seperti halnya sifat dan sikap kearab-araban, gambar kelompok radikal dan pemimpin paham/gerakan radikal diberi teks jenaka. Kaum muda penentang paham radikal menilai bahwa kelompok-kelompok berpaham radikal seringkali meresahkan masyarakat dan menciptakan konflik-konflik horizontal dalam masyarakat. Para pimpinan paham radikal pun dianggap sering memprovokasi masyarakat sehingga terjadi konflik antar unsur masyarakat.

Ketiadaan pemikiran kritis digambarkan dengan meme berikut: a) pembedahan kepala manusia dan mengosongkan otaknya; b) tulisan ala timur tengah yang bukan dari kitab suci. Penggambaran tersebut merupakan penilaian kaum muda penentang paham radikal atas kaum muda pendukung yang seringkali melakukan tindakan tanpa berpikir terlebih dahulu, mencocok-cocokkan suatu fenomena dengan paham/ajaran yang mereka percayai meskipun tidak memiliki relevansi yang kuat dan bahkan dibuat-buat. Penggambaran tulisan ala timur-tengah ditujukan sebagai ironi terhadap kaum muda pendukung paham radikal yang ternyata mengagungkan teks daripada substansinya. Teks-teks tersebut justeru bukan berupa ayat suci, melainkan hanya kalimat percakapan biasa, atau bahkan kutipan do'a dari agama lain yang ditulis dalam tulisan ala timur-tengah.

Pengingkaran atas realitas majemuk Indonesia digambarkan terutama saat menjelang hari besar keagamaan atau hari besar nasional. Kaum muda berpaham radikal seringkali menyerukan pelarangan pengucapan selamat hari raya agama lain. Meme yang tertampil dalam hal ini meliputi: a) pengharaman pengucapan selamat atas hari raya agama lain, tetapi boleh menerima hadiah dari kelompok agama lain; b) tokoh paham radikal yang menyerukan pelarang ucapan atas hari raya atau hari nasional; dan c) wajah manusia yang dikaikan dengan kejadian hari raya atau hari nasional. Visualisasi pengharaman atas ucapan selamat terhadap hari raya suatu agama atau hari nasional merupakan bentuk parodi atas kaum muda pendukung paham radikal yang seringkali mudah mengkafirkan kelompok lain dan intoleran. Dari pengkafiran tersebut, kaum muda penentang paham radikal kemudian mengembangkan meme pelarangan perayaan atas hari nasional, semisal pelarangan hari Kartini karena Ibu Kartini tidak berkerudung dibubuhi dengan kata-kata jenaka. Meme wajah tokoh paham radikal juga dijadikan parodi atas provokasi mereka terhadap pengkafiran kaum lain dan intoleran terhadap perbedaan. Wajah tokoh nasional yang menggagas suatu peristiwa nasional merupakan ironi atas ketiadaan penghargaan dari pendukung paham radikal terhadap tokoh-tokoh nasional yang dianggap berjasa terhadap bangsa.

Meme yang nampak bersifat sederhana, merupakan arena bertemunya makna-makna budaya dan merupakan gerakan bagaimana suatu hegemoni ditentang (Hall, 1996a). Di dalam komunikasi visual meme tersimpan suatu kekuatan politik khas kaum muda yang efektif untuk melakukan perlawanan terhadap hegemoni. Meme direproduksi oleh khalayak yang mengkonsumsinya dan diartikulasikan menjadi komunikasi verbal. Dengan demikian, perlawanan terhadap hegemoni berubah menjadi komunikasi verbal yang dilakukan oleh khalayak kaum muda. 


\section{KOMUNIKASI VERBAL}

Dari tampilan-tampilan meme, artikulasi visual berubah menjadi verbal. Arena memperebutkan makna-makna kultural meluaskan bentuknya pada bentuk komunikasi verbal yaitu percakapan yang dijadikan kosakata khas kaum muda. Kosakata baru kemudian diperluas dalam lingkungan kaum muda sehingga dikenali sebagai bentuk budaya yang dihasilkan oleh kaum muda. Kosakata dalam konteks artikel ini adalah kosakata yang memiliki kaitan dengan penentangan terhadap paham radikal dan juga penentangan terhadap kaum muda pendukung paham radikal.

Meme yang tertampil sebelumnya sebagai komunikasi visual perlawanan kaum muda terhadap hegemoni paham radikal diekstraksikan dalam artikulasi kata verbal baik secara lisan maupun tulisan. Merujuk pada gambar-gambar yang tertampil dalam meme, kaum muda penentang paham radikal mengekstraksikannya menjadi istilah-istilah yang ditujukan bagi keberadaan kaum muda pendukung paham radikal. Istilah-istilah yang dihasilkan kemudian disebarluaskan sebagai bagian dari budaya populer kaum muda seperti yang dinyatakan oleh Brake (1985). Komunikasi verbal ini disebarluaskan dan hanya dimengerti dalam alam pengalaman kaum muda, dengan kata lain menjadi suatu simbol dalam kehidupan kaum muda, khususnya penentang paham radikal. Simbolsimbol tersebut semakin meneguhkan identitas budayanya, yakni budaya kaum muda kontemporer dalam arena perebutan maknamakna kultural, sebagaimana dinyatakan oleh Tittley (1999), Hebdige (1979), Hall (1996), Bennet (2002 dan 2006).

Istilah-istilah yang dihasilkan merupakan hasil penilaian kaum muda penentang paham radikal terhadap kaum muda pendukung paham radikal. Sebagaimana meme yang dihasilkan, istilah-istilah yang dihasilkan oleh kaum muda penentang paham radikal meliputi: a) unta; b) fentung; c) tafir; d) $2 d$; e) cocokologi; f) indonistan; dan g) takebeer. Masing-masing istilah memiliki makna yang berbeda-beda dalam menganggapi kaum muda berpaham radikal. Untuk memudahkan pemerian mengenai teks, deskripsi, dan fungsi komunikasi verbal kaum muda dalam melawan hegemoni paham radikal, tersaji dalam tabel di bawah.

Tabel 4

Teks, Deskripsi, dan Fungsinya Sebagai Komunikasi Verbal Dalam Budaya Populer Kaum Muda Sebagai Bentuk Perlawanan Terhadap Hegemoni Paham Radikal

\begin{tabular}{|c|c|c|}
\hline Teks & Deskripsi & Fungsi \\
\hline Unta & $\begin{array}{l}\text { pendukung paham radikal } \\
\text { yang lebih mengedepankan } \\
\text { ciri-ciri ketimur-tengahannya } \\
\text { daripada keIndonesian }\end{array}$ & $\begin{array}{l}\text { Perlawanan secara verbal } \\
\text { dalam bentuk ironi/parodi } \\
\text { terhadap artikulasi verbal } \\
\text { bahasa timur tengah yang } \\
\text { menunjuk pada form } \\
\text { bukan pada substansi }\end{array}$ \\
\hline Fentung & $\begin{array}{l}\text { tindakan dari kelompok } \\
\text { radikal yang kerap melakukan } \\
\text { tindakan kekerasan dengan } \\
\text { menggunakan senjata dari } \\
\text { kayu atau pentungan }\end{array}$ & $\begin{array}{l}\text { Perlawanan secara verbal } \\
\text { dalam bentuk ironi/ } \\
\text { parodi terhadap tindakan } \\
\text { kekerasan yang dilakukan } \\
\text { oleh kelompok radikal }\end{array}$ \\
\hline Tafir & $\begin{array}{l}\text { kaum muda radikal kerap } \\
\text { secara mudah memberi } \\
\text { label kafir kepada kelompok } \\
\text { ataupun individu-individu } \\
\text { yang berbeda atau } \\
\text { menentang mereka }\end{array}$ & $\begin{array}{l}\text { Perlawanan secara verbal } \\
\text { ironi/parodi terhadap } \\
\text { sikap mudah mengkafirkan }\end{array}$ \\
\hline $2 d$ & $\begin{array}{l}\text { tingkat intelektualitas } \\
\text { kaum muda radikal yang } \\
\text { tidak memiliki pemikiran } \\
\text { kritis, mudah terprovokasi, } \\
\text { kepatuhan kaku, dan tidak } \\
\text { terbuka terhadap realitas } \\
\text { majemuk bangsa Indonesia }\end{array}$ & $\begin{array}{l}\text { Perlawanan secara } \\
\text { verbal dalam bentuk } \\
\text { ironi/parodi terhadap } \\
\text { tingkat pengetahuan atau } \\
\text { wawasan kelompok radikal }\end{array}$ \\
\hline cocokologi & $\begin{array}{l}\text { perilaku menghubungkan } \\
\text { suatu fenomena tanpa dapat } \\
\text { dipertanggungjawabkan } \\
\text { kebenarannya secara ilmiah, } \\
\text { sejarah, dan ilmu tafsir }\end{array}$ & \begin{tabular}{|l|} 
Perlawanan secara verbal \\
dalam bentuk ironi/ \\
parodi terhadap tindakan \\
menghubung-hubungan \\
suatu fenomena tanpa \\
dasar yang kuat \\
\end{tabular} \\
\hline indonistan & $\begin{array}{l}\text { Sikap chauvinis kelompok } \\
\text { radikal yang menganggap } \\
\text { dirinya paling benar dan } \\
\text { menganggap bahwa budaya- } \\
\text { budaya di Indonesia lebih } \\
\text { rendah daripada budaya } \\
\text { kelompok radikal }\end{array}$ & $\begin{array}{l}\text { Perlawanan verbal } \\
\text { terhadap golongan radikal } \\
\text { yang ingin membentuk } \\
\text { budaya Indonesia seperti } \\
\text { budaya timur-tengah }\end{array}$ \\
\hline takebeer & $\begin{array}{l}\text { tindakan kekerasan yang } \\
\text { dilakukan oleh kelompok } \\
\text { radikal yang seolah-olah } \\
\text { kehilangan akal sehat }\end{array}$ & $\begin{array}{l}\text { Perlawanan verbal } \\
\text { terhadap tindakan } \\
\text { kekerasan membabi- } \\
\text { buta yang dilakukan oleh } \\
\text { golongan radikal }\end{array}$ \\
\hline
\end{tabular}

Sumber: hasil penelitian tahun 2014-2015 
Istilah unta ditujukan kepada kaum muda pendukung paham radikal yang lebih mengedepankan ciri-ciri ketimur-tengahannya daripada keIndonesian. Peristilahan unta diturunkan dari tampilan visual yang tertuang dalam meme yang mengambarkan sikap dan sifat kaum muda pendukung paham radikal. Dalam kesehariannya, kaum muda pendukung paham radikal seringkali mengganti kosakata baku bahasa Indonesia menjadi kosakata yang terdapat dalam bahasa timur-tengah agar dipandang lebih islami. Dari pandangan kaum muda penentang paham radikal, hal terpenting adalah bukan pada artikulasi verbal dalam bahasa timur-tengah, tetapi substansi atau makna dari kosakata yang dapat dipahami sebagai kebenaran dalam wujud lokalitas atau membumi.

Kata fentung, merupakan parodi dari kata pentung. Kata verbal fentung menggambarkan tindakan dari kelompok radikal yang kerap melakukan tindakan kekerasan dengan menggunakan senjata dari kayu atau pentungan. Huruf "p" diubah menjadi "f" sebagai ironi atas penggunaan dialek bahasa timur tengah daripada penggunaan bahasa Indonesia. Dari pandangan kaum muda penentang paham radikal, kaum radikal sering meresahkan masyarakat karena tindakantindakan mereka yang kerap melakukan kekerasan dan memancing konflik horizontal dalam masyarakat.

Kata tafir, sebagaimana halnya kata fentung, merupakan parodi dari kata kafir. Kaum muda radikal kerap secara mudah memberi label kafir kepada kelompok ataupun individu-individu yang berbeda atau menentang mereka. Tafir juga menunjuk kepada binatang tafir, yakni binatang yang berbeda dengan unta dan bukan binatang khas timur tengah. Tindakan mengkafirkan pihak lain oleh kaum radikal dijadikan parodi dan juga simbol sebagai bentuk perlawanan. Dari pandangan kaum muda penentang paham radikal, pelabelan kafir adalah mutlak milik Tuhan, seseorang menjadi kafir atau tidak, bukan ditentukan oleh anggapan manusia, baik secara individual maupun kelompok.

Istilah $2 d$ atau dua digit menunjuk pada derajat nilai intellectual quotion (IQ). Kaum radikal yang tidak memiliki pemikiran kritis, patuh secara kaku terhadap pimpinannya, mengabaikan realitas majemuk, sangat percaya pada situs-situs radikal yang memberikan informasi meski kebenarannya tidak dapat dipertanggungjawabkan, dan juga mudah diprovokasi agar menuruti keinginan kaum radikal untuk memecahbelah bangsa. Dari pandangan kaum muda penentang paham radikal, kaum muda radikal telah dibutakan akal sehatnya sehingga mereka tidak memiliki pemikiran kritis dan tidak terbuka terhadap realitas majemuk bangsa Indonesia. Dengan kata lain, kaum muda pendukung paham radikal dinilai sebagai orang yang tidak mampu berpikir sehingga nilai dari IQnya hanya mencapai dua digit atau bernilai 0-99. Sebagai keterangan lanjutan, nilai IQ di bawah 100 adalah nilai kecerdasan di bawah manusia normal pada umumnya.

Istilah cocokologi merupakan sindiran terhadap kaum radikal yang gemar mencocokkan suatu peristiwa dengan ayat suci tanpa bisa dipertanggungjawabkan kebenarannya, baik dari sisi ilmiah, sejarah, maupun ilmu tafsir. Kaum radikal seringkali menghubungkan suatu peristiwa dengan gejala alam atau dengan ayat suci secara tekstual namun tidak mempertimbangkan makna kontekstualnya. Dari pandangan kaum muda penentang paham radikal, hal tersebut memiliki potensi yang sangat berbahaya 
karena secara halus dapat menyesatkan pikiran dan dapat mengabaikan bukti-bukti ilmiah, sejarah, ataupun konteks dalam ilmu tafsir. Kaum muda penentang paham radikal berpandangan, bahwa pencocokkan tersebut dapat menggiring kaum muda untuk tidak menggunakan nalar dan akal sehatnya yang pada muaranya akan menghasilkan kaum muda yang dogmatis secara sempit.

Istilah indonistan diciptakan sebagai satir terhadap sikap chauvinis kaum radikal yang menganggap bahwa dirinya lebih benar daripada kelompok lain di luarnya. Standar nilai yang digunakan adalah standar nilai timurtengah bukan standar nilai yang berkembang di dalam masyarakat Indonesia. Kaum muda penentang paham radikal berpandangan bahwa setiap budaya yang hidup di Indonesia adalah sederajat dan unik, tidak dapat dikatakan bahwa satu budaya lebih baik daripada budaya lainnya.

Kata takebeer merupakan parodi dari tindakan kaum radikal yang melakukan aksi kekerasan. Kata takebeer ini sendiri terdiri dari dua kata dalam bahasa Inggris, yakni take dan beer (sejenis minuman keras) yang jika disatukan menjadi bermakna "ambil bir". Menurut kaum muda penentang paham radikal, manusia normal tentu akan menghindari tindakan kekerasan dalam aksi mereka, hanya orang mabuk yang mungkin melakukan tindakan kekerasan. Tindakan-tindakan kekerasan yang dilakukan oleh kaum radikal tak ubahnya seperti manusia yang sedang mabuk, oleh karenanya istilah takebeer tidak relevan dengan istilah takbir, tetapi lebih menunjuk pada kaum radikal yang seperti orang mabuk saat melakukan tindakannya.

Untuk memudahkan penggambaran data, dapat dilihat pada tabel 4 berikut di bawah. Tabel 4 tersebut menerangkan teks, dan deskripsi dari komunikasi verbal yang dihasilkan menjadi kosa kata khas dalam budaya populer remaja sebagai bentuk perlawanan terhadap paham radikal yang menghegemoni sebagian kaum muda lainnya.

Istilah-istilah verbal ini dikenal di kalangan kaum muda khususnya yang termasuk dalam golongan penentang paham radikal. Seperti yang dinyatakan oleh Tittley (1999), kekuatan-kekuatan budaya mereka dinegosiasikan dalam kehidupan sehari-hari yang aktual untuk memperoleh pengakuanpengakuan atas tindakan mereka dalam melawan hegemoni. Di sisi lain, bentuk perlawanan yang tertampil tidak lepas dari gaya-gaya yang menunjukkan kaum muda. Sebagaimana dinyatakan oleh Bennett (2002, 2006), kaum muda menunjuk pada suatu kategori khas dalam masyarakat, tidak semata berbicara usia. Tindakan-tindakan yang tertampil dalam perlawanan kaum muda terhadap paham radikal menunjukkan suatu perlawanan khas yang meneguhkan suatu kategori khas dalam masyarakat yang lebih luas.

\section{SIMPULAN}

Budaya populer tidak hanya berbicara mengenai polaritas antara budaya tinggi dan budaya massa, tetapi menyangkut juga pada relasi, negosiasi, dan perjuangan maknamakna budaya dalam perebutan arena-arena budaya. Dalam arena tersebut, budaya populer menjadi tempat suatu hegemoni diterima atau ditentang. Budaya populer kontemporer merupakan tindakan-tindakan kreatif dari kelompok masyarakat dalam menanggapi kondisi sosial yang terjadi pada strukturnya yang lebih luas. Tindakan-tindakan kreatif dalam melawan hegemoni, tertampil dalam 
wujud komunikasi visual dan verbal yang mengedepankan gaya-gaya kaum muda dalam merepresentasikan diri mereka dalam merespon suatu peristiwa yang terjadi dalam masyarakat.

Perlawanan dari kaum muda terhadap hegemoni paham radikal keagamaan merupakan tindakan-tindakan aktif mereka dalam memperebutkan arena kultural. Kreativitas yang tertampil sangat mengedepankan pada artikulasi-artikulasi visual dan verbal yang sederhana namun efektif dalam mempengaruhi strukturnya yang lebih besar dan juga berkaitan sebagai peneguhan posisi dan identitas sebagai kaum muda yang dinamis dan memiliki idealisme kebangsaan yang tertampil secara khas dan berbeda. Dalam kehidupan kaum muda kontemporer, budaya populer menjadi alat perlawanan terhadap paham-paham yang dianggap menghegemoni kehidupan mereka sekaligus juga menjadi media penyadaran terhadap ancaman yang dihadapi oleh bangsa Indonesia dewasa ini.

Di balik satir, parodi, dan ironi yang ditampilkan, terdapat suatu ajakan bagi kaum muda untuk bersikap rasional dan selalu melakukan tindakan-tindakan kritis agar terhindar dari sifat-sifat yang dianggap naif seperti yang dilakukan oleh kaum muda pendukung paham radikal. Dari budaya populer kontemporer kaum muda penentang paham radikal yang dapat dimaknai bahwa mereka menginginkan agar kaum muda tidak terhegemoni oleh paham radikal yang tidak sesuai dengan nilai-nilai budaya bangsa Indonesia.

\section{DAFTAR PUSTAKA}

Abuza, Zachary, 2007. Political Islam And Violence In Indonesia, New York: Routledge.
Ahnaf, M.,I., 2013. Struktur Politik dan Deradikalisasi Pendidikan Agama Bagi Anak Muda di Indonesia. Jurnal Pendidikan Islam. Vol. II No. 1, Juni 2013.

Azca, Muhammad N., 2011. Yang Muda Yang Radikal: Refleksi Sosiologis Terhadap Fenomena Radikalisme Kaum Muda Muslimdi Indonesia Pasca Orde Baru, Maarif, Vol. 8, No.1, Juni 2011, hal 27, http:maarifinstitute.org/ images/../ vol\%20viii\%20no\%201\%20juli\%2 0201. pdf, diakses pada tanggal 2 Maret 2015.

Bennett, Andy, 2002. Researching Youth Culture And Popular Music: A Methodological Critique. The British Journal of Sociology. Vol 53, No. 1, 451-466 2006. 'Punk's Not Dead: The Significance of Punk Rock for an Older Generation of Fans', Sociology, 40(1): 219-35.

Brake, M. 1985. Comparative youth culture: The Sociology of Youth Culture and Youth Subcultures in America, Britain and Canada. Boston MA: Routledge \& Kegan.

Bruinessen, Martin V, 2002. Genealogies Of Islamic Radicalism in Post Suharto Indonesia, South East Asia Research. Vol. 10, No. 2, tahun 2002 hal 117, http:/// www. dspace.library.uu.nl/ bitstream/ handle/1874/20378/bruinessen _02_genealogies_islamicradicalism. pdf?sequence $=1$, diakses pada tanggal 3 Maret 2015.

Brown, Daniel, 2005. The State And Ethnic Politics In South East Asia. London: Routledge

Clarke, J., 1975. Subcultures, Cultures and Class, dalam S. Hall \& T. Jefferson (ed.). Resistance Through Rituals, London: Routledge. 
Grotevant, H. D., \& Cooper, R., C., 2005. Individuality and Connectedness in Adolescent Development. U E. Elisabeth \& A. E. Skoe (Eds.) Personality Development in Adolescence: A cross national and life span perspective. London and New York: Routledge.

Hall, Stuart, 1996a. Who Needs "Identity"? Dalam Hall, S, dan P. Du Gay (eds.) Questions of Cultural Identity, London: Sage. 1996b. On Postmodernism and Articulation: An Interview with Stuart Hall', in D. Morley and Chen, K. H. (eds.), Stuart Hall: Critical Dialogues, London: Routledge.

Hebdige, Dick, 1979. Subculture: The Meaning OfStyle. London And New York: Routledge

Hendry, L.B., Shucksmith J., Love, J.G., dan Glendinning, A. 2005. Young People's Leisure and Lifestyle. London: Routledge.

Henley, D. and Davidson, J.S., 2003. The Revival of Tradition In Indonesian Politics: The Deployment of Adat from Colonialism To Indigenism. New York: Routledge.

Hodkinson P., dan Deicke, W., 2007. Youth Cultures: Scenes, Subcultures And Tribes. London and New York: Routledge

Kingsburry, D., 2003. Power Politics And The Indonesian Military. New York: Routledge Curzon.
Munip, Abdul, 2012. Menangkal Radikalisme Agama Di Sekolah, Jurnal Pendidikan Islam, Vol.1 No 2. Desember 2012, hal 160, http:// journal.uin-suka.ac.id/jurnal/ artikel/133/menangkal-radikalismeagama-di-sekolah, diakses tanggal 2 Februari 2015.

Salim, Hairus, Kaelani, Najib, dan Azekiyah, Nikmal, 2011. Politik Ruang Publik Sekolah Negosiasi di Sekolah Menengah Umum Negeri Di Yogyakarta, Yogyakarta: UGM.

Tittley, M. 1999.Youth Subcultures and Commitment Level Model, sebuah essay diterbitkan melalui jaringan internet http://www.btc.co.za. (diakses pada tanggal 12 Januari 2013, pukul 11.00 WIB)

Vatiokis, M.R.J, 2003. Indonesian Politics Under Suharto: Rise And Fall The New Order $3^{\text {rd }}$ Edition. New York: Routledge.

Woodward, M., 2011. Java, Indonesia, And Islam. Heidelberg-London-Ney York: Springer www.swatt-online.com/2011/04/lakippemerintah-harus-tinjau-kembali pendidikan-agama-islam. Diakses tanggal 15 Mei 2015. 


\title{
PANDUAN PENULISAN
}

\author{
Jurnal Mamangan Edisi III, Program Studi Pendidikan Sosiologi \\ STKIP PGRI Sumatera Barat
}

\section{a. Pendahuluan}

Setiap tulisan ilmiah, baik berupa essay, makalah, jurnal, laporan penelitian dan buku memiliki karakteristik tersendiri sesuai dengan selera penulis, penerbit, sponsor penelitian dan atau aturan-aturan tertentu sesuai dengan ruang dan waktu dimana tulisan dibuat oleh penulis. Selain itu, karakteristik sebuah tulisan ilmiah juga menggambarkan karakter institusi dimana sebuah tulisan diterbitkan. Meskipun demikian sebuah tulisan ilmiah tentulah memiliki standar minimum yang harus dipenuhi. Standar minimum tersebut terkait dengan substansi isi dan aspek teknis dalam penulisannya. Dengan dua standar yang ada sebuah tulisan ilmiah dapat dipertanggungjawabkan secara akademis.

Mengikuti logika umum penulisan ilmiah, ragam bentuk dan karakteristik tulisan ilmiah yang berlaku umum dalam khasanah akademik maupun praktis sebagaimana diuraikan di atas, untuk menjadikan Jurnal Mamangan sebagai sebuah karya ilmiah, program studi sosiologi juga menginginkan jurnal Mamangan memiliki karakter yang kuat dan spesifik dalam kerangka isu dan bentuk penulisan. Karakter dan spesifikasi yang kuat antara lain dapat diatur melalui dua hal, pertama substansi isi. Substansi isi diatur melalui tema dan isu utama tulisan pada masing-masing edisi jurnal yang ditetapkan oleh redaksi. Paling tidak, tulisan yang ada dalam satu edisi memiliki isu utama yang sama dalam kacamata disiplin ilmu yang berbeda, sehingga jurnal melahirkan pembahasan isu dengan multiparadigma. Dengan khasanah ilmu yang berbeda tersebut kemudian isu utama jurnal pada masing-masing edisi akan memiliki perspektif yang banyak dan isu utama dapat dibahas secara utuh dan kokoh.

Kedua pengaturan teknis dan sistematika penulisan. Pengaturan teknis dan sistematika penulisan bertujuan untuk menyamakan pola dan kerangka penulisan yang hendak dimuat dalam jurnal. Pengaturan teknis dan sistematika penulisan ini sekaligus bertujuan untuk membantu penulis dalam mengerangkakan tulisan ilmiah yang akan dikirimkan ke Jurnal Mamangan Diharapkan dengan pengaturan format makalah secara substansi dan teknis, jurnal Mamangan memiliki karakter yang kuat dan khas dalam secara ilmiah.

\section{b. Tujuan}

Pengaturan teknis dan format penulisan ini tidak berpretensi untuk menggurui atau bahkan mengajarkan kepada partisipan tentang bagaimana cara menulis ilmiah yang baik dan benar, tapi pengaturan format ini tidak labih dari sekedar menyamakan persepsi tentang substansi dan format tulisan yang diinginkan dalam jurnal yang direncanakan. Sehingga, penulisan panduan ini hanya sebatas untuk menyamakan pola dan kerangka dasar penulisan untuk tema yang sama dalam kacamata yang berbeda.

\section{c. Teknis dan Format Penulisan}

1. Naskah merupakan karya ilmiah original penulis dan tidak mengandung unsur plagiarisme;

2. Naskah ditulis dalam Bahasa Indonesia atau Bahasa Inggris;

3. Naskah menggunakan istilah yang baku serta bahasa yang baik dan benar;

4. Naskah diketik dengan program Microsoft Word, huruf Cambria, ukuran 12 pts, spasi 1, kertas ukuran A4, 12-17 halaman; 
5. Naskah diserahkan dalam bentuk soft copy ke email redaksi, redaksimamangan@gmail.com

6. Sistematika penulisan artikel:

a) Judul: maksimal 14 kata dalam bahasa Indonesia dan 12 kata dalam bahasa Inggris; ditulis dengan huruf kapital, ukuran 12 pts;

b) Nama Penulis: tanpa mencantuman gelar akademik. Artikel yang ditulis oleh lebih dari satu orang, harus mencantumkan setiap nama penulis, dengan meletakkan nama penulis utama di urutan awal; nama penulis diikuti dengan mencantumkan alamat email.

c) Lembaga: dicantumkan di bawah alamat email setelah nama penulis;

d) Abstrak dan Kata Kunci (keyword): Abstrak ditulis dalam dua bahasa, yaitu Bahasa Inggris dan Bahasa Indonesia. Panjang abstrak maksimal 200 kata, dan kata kunci (keyword) maksimal 5 kata. Abstrak memuat tujuan, metode, dan hasil penelitian;

e) Pendahuluan: berisi latar belakang masalah, konteks penelitian, telaah pustaka, dan tujuan penelitian. Seluruh bagian pendahuluan diuraikan secara terintegrasi dalam bentuk paragraf-paragraf;

f) Literature review atau kerangka teori : bagian ini merupakan uraian penulis tentang penelusuruan penelitian terdahulu atau kajian teoritis yang digunakan dalam artikel. Literature review atau kerangka teori maksimal 2 halaman.

g) Metode Penelitian: berisi uraian tentang rancangan teknis-prosedural penelitia, berupa setting lokasi penelitian, jenis data penelitian, teknik pengumpulan data, analisis data, dan penyajian data. dapat juga ditambahkan paradigma penelitian;

h) Hasil/ Temuan Penelitian/ Analisis: merupakan hasil analisis yang berkaitan dengan pertanyaan penelitian. Setiap temuan data penelitian haur dibahas. Pembahasan berupa pemaknaan, interpretasi, dan pendekatan atau pembacaan teori terhadap data yang diperoleh;

i) Simpulan: bagian ini terdiri dari temuan penelitian yang merupakan jawaban atas pertanyaan penelitian atau merupakan intisari dari hasil pembahasan. Kesimpulan disajikan dalam bentuk paragraf;

j) Daftar Pustaka: hanya memuat sumber-sumber yang dirujuk, dan setiap sumber yang dirujuk harus tercantum dalam daftar pustaka. Rujukan berupa sumber-sumber primer yang terdiri dari hasil penelitian, artikel jurnal, dan penelitian sripsi, tesis dan disertasi;

k) Biodata Penulis: berupa nama, tempat tanggal lahir, alamat, lembaga, alamat email, nomor telepon/HP, pendidikan dan pekerjaan, serta publikasi karya/tulisan terbaru.

\section{Contoh penulisan Daftar Pustaka:}

\section{Buku:}

Anderson, D.W., Vault, V.D \& Dickson, C.E. Problems dan Prospects for the Decades Ahead: Competency Based Teacher Education. Berkeley: McCutchan Publishing Co, 1999.

\section{Buku kumpulan artikel:}

Saukah, A. \& Waseso, M.G. (Eds.). Menulis Artikel untukJurnal Ilmiah (edisi ke-4, cetakan ke-1). Malang: UM Press, 2002.

\section{Artikel dalam buku kumpulan artikel:}

Russel, T. An Alternative Conception: Representing Representation. Dalam P.J. Black \& A. Lucas (Eds.), Children's Informal Ideas in Science (hal. 62-84). London: Routledge, 1998.

\section{Artikel dalam jurnal atau majalah:}

Kansil, C.L. Orientasi Baru Penyelenggaraan Pendidikan Program Profesional dalam Memenuhi Kebutuhan Dunia Industri. Transpor, XX (4): 57-61, 2002.

\section{Artikel dalam koran:}

Pitunov, B. Sekolah Unggulan ataukah Sekolah Pengunggulan? Kompas, hlm. 4 \& 11, 13 Desember, 2002.

\section{Tulisan/berita dalam koran (tanpa nama pengarang):}

Republika. Wanita Kelas Bawah Lebih Mandiri, hal. 3, 22 April 2013. 


\section{Dokumen resmi:}

Pusat Pembinaan dan Pengembangan Bahasa. Pedoman Penulisan Laporan Penelitian. Jakarta: Depdikbud. Undangundang Republik Indonesia Nomor 2 tentang Sistem Pendidikan nasional. Jakarta: PT Armas Duta Jaya, 1978.

\section{Buku terjemahan:}

Ary, D., Jacobs, L.C. \& Razavieh, A. 1976. Pengantar Penelitian Pendidikan. Terjemahan oleh Arif Furchan. Surabaya: Usaha Nasional, 1982.

\section{Skripsi, Tesis, Disertasi, Laporan Penelitian:}

Kuncoro, T. Pengembangan Kurikulum Pelatihan Magang di STM Nasional Malang Jurusan Bangunan, program Studi Bangunan Gedung: Suatu Studi Berdasarkan Kebutuhan Dunia Usaha Jasa Konstruksi. Tesis. Malang: PPS IKIP MALANG, 1996.

\section{Makalah seminar, lokakarya, penataran:}

Waseso, M.G. Isi dan Format Jurnal Ilmiah. Makalah. Seminar Lokakarya Penulisan Artikel dan Pengelolaan Jurnal Ilmiah, Universitas Lambung Mangkurat, Banjarmasin, 9-11 Agustus, 2001.

\section{Internet (karya individual):}

Hitchcock, S., Carr, L. \& Hall, W. A Survey of STM Online Journals, 1990-1995: The Calm before the Storm, 1996. (http:// journal.ecs.soton.ac.uk/survey/survey.html,diunduh 12 Juli 2011).

\section{Internet (artikel dalam jurnal online):}

Kumaidi. 1998. Pengukuran Bekal Awal Belajar dan Pengembangan Tesnya. Jurnal Ilmu Pendidikan. (Online), Jilid 5, No. 4, (http://www.malang.ac.id, diunduh 20 Januari 2011).

\section{Internet (bahan diskusi):}

Wilson, D. 20 November 1995. Summary of Citing Internet Sites. NETTRAIN Discussion List, (Online), (NETTRAIN@ ubvm.cc.buffalo.edu, diunduh 22 Oktober 2010.

\section{Internet (email pribadi):}

Naga, D. S. (ikip-jkt@indo.net.id). 1 Oktober 2011. Artikel untuk Turast. E-mail kepada Subhan Ajrin (subhanajrin@ gmail.com). 


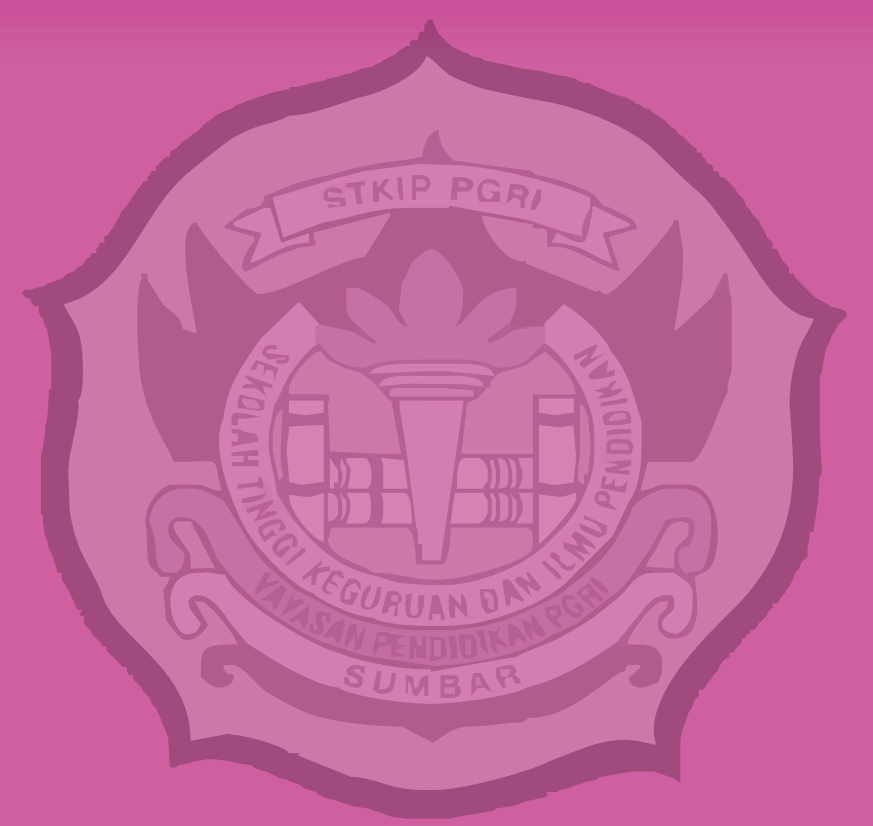

Penerbit:

Laboratorium Program Studi Pendidikan Sosiologi, STKIP PGRI Sumbar Alamat: Kampus STKIP PGRI, Jl. Gunung Pangilun, Padang, Sumatera Barat Email: redaksimamangan@gmail.com 